FACTA UNIVERSITATIS

Series: Linguistics and Literature Vol. $18, \mathrm{~N}^{\circ} 1,2020$, pp. 109-118

https://doi.org/10.22190/FULL2001109S

Original Scientific Paper

\title{
AN ANALYSIS OF PHONETIC-PHONOLOGICAL AND ORTHOGRAPHIC ERRORS WHEN LEARNING SERBIAN AS A FOREIGN LANGUAGE
}

\author{
UDC 811.163.41'243-057.87 \\ $811.163 .41 ' 342.2$
}

\begin{abstract}
Nina Lj. Sudimac
University of Niš, Faculty of Philosophy, Serbian Department, Niš, Serbia
\end{abstract}

\begin{abstract}
From the perspective of applied linguistics, this paper deals with the acquisition of Serbian as a foreign language by learners whose mother tongues are Lithuanian, Japanese, English and Bulgarian, and who spent one semester at the Centre for Serbian as a Foreign and Second Language at the Faculty of Philosophy in Niš. Working with a specific sample and using the analytical and error analysis method, we aim to identify the most common errors the speakers make at the phonetic-phonological and orthographic level,., the identified linguistic errors are classified into (a) errors occurring under the influence of the mother tongue; $(b)$ errors as the result of the strict rules of the Serbian language system itself - interlingual errors; (c) errors arising from knowledge of another second language; and $(d)$, errors resulting from the insecurity and insufficient acquisition of the Serbian language. By analyzing the sample, we conclude that the greatest number of errors at the phonetic-phonological and orthographic level occurred under the influence of their mother tongue (L1) on Serbian (L2).
\end{abstract}

Key words: error analysis, phonetic-phonological level, orthographic level, Serbian as a foreign language (L2)

\section{INTRODUCTION}

In the past ten years, the development of student mobility programs has influenced the increase in the number of foreigners interested in learning Serbian. An increasing number of foreigners from different countries of the world have visited university centers where this type of teaching is offered. The principles of foreign language teaching show that the methodology of work and teaching must be adapted to each learner since there are

Submitted April 24, 2020; Accepted May 2, 2020

Corresponding author: Nina Sudimac

University of Niš, Faculty of Philosophy

E-mail: nina.sudimac@filfak.ni.ac.rs 
differences between one's mother tongue and the language learned. As teaching Serbian as a foreign language is still in its infancy, it is necessary to conduct research which will show the specific aspects of working with students from certain language communities. So far, the literature has sporadically addressed the issue of errors foreigners make when learning Serbian (cf. Babić 2016; Milošević 2016; Perišić and Arsić 2016; Đorđević 2017; Sudimac 2019), and has suggested that there are common errors, but also errors which occur as a consequence of the interference of the learner's mother tongue and the Serbian language. The literature has described the acquisition of phonological systems of foreign languages, and the existence of different models of foreign language acquisition, explaining them in relation to the phonological system of their mother tongue. The influence of the mother tongue (L1) on the acquisition of a foreign language (L2) is explained by the fact that the phonemes which are different will sooner be acquired than similar ones which exist in both languages (Flege 1993, 1995), i.e. two sounds which exist in a foreign language will merge into one which exists in the mother tongue and adapt to the vowel space of the mother tongue (Best 1995).

The practice of Serbian as a foreign language shows that foreigners who learn Serbian have difficulty in learning phonetics and phonology, although in theory the situation should be reversed because of the existence of the so-called phonetic principle (each letter corresponds to one phoneme and vice versa) in Serbian. At the same time, it has been observed that the interference of the mother tongue either helps or makes things difficult for foreigners in acquiring the phonological system of the Serbian language. For this reason, we will attempt to draw some conclusions from the research conducted, which would help teachers of Serbian as a foreign language organize their classes. The subject of this paper is the analysis of errors at the phonetic-phonological and orthographic level made by students when learning Serbian who spent one semester at the Faculty of Philosophy in Niš, whose native language is Lithuanian, Japanese, English or Bulgarian.

\section{PREVIOUS RESEARCH}

We formulated the following research questions:

1. To what degree is the Serbian language acquired at the phonetic-phonological level after seventy classes?

2. How successful are the learners in mastering the orthographic rules of standard Serbian?

3. What errors can be noted in each learner and how can they be explained?

Therefore, the main task of this paper is to identify errors which exist in learning Serbian as a foreign language, and then to describe and explain them as well as to perform a typological classification using analytical, qualitative and error analysis methods.

The research was conducted in January, 2020 at the Centre for Serbian as a Foreign and Second Language at the Faculty of Philosophy in Niš. The participants in this research were four female students, from the USA, Japan, Lithuania and Bulgaria, who successfully passed the beginner Serbian language course (A1 level), which they attended from October 7, 2019 to January 20, 2020. The learners had classes five times a week in the classrooms of the Centre for Serbian as a Foreign and Second Language. During the course, the textbook ${ }^{1}$

\footnotetext{
${ }^{1}$ For more information on the quality of the used textbook and workbook, see Novaković $(2018 ; 2019)$.
} 
Reč po reč (2015) was used. In addition to the textbook, we also used the workbook Reč po reč (2015), which the learners used to do homework (in addition to the tasks we created for the learners), as well as listen to the audio material.

For the purpose of this research, a specially designed questionnaire was used as an instrument to examine the reading and writing skills of the learners: primarily, the acquisition of the consonant system of standard Serbian was studied. There were five questions in total: the first two exercises evaluated the orthographic level of language proficiency - the first exercise required transcribing a text from Latin to Cyrillic, and in the second, learners wrote down words which we read out to them. The third exercise tested the knowledge of the meaning of words - pairs, in which a consonant or a vowel phoneme bears a distinction in semantic terms. The last two questions checked the production of primary consonant units of standard Serbian - learners read words or a shorter paragraph. Each candidate took the test under the same conditions, i.e. individually, at different time intervals and in the presence of their teacher. The results obtained were analyzed by qualitative data processing methods, and are presented below.

Learners make errors due to the exposure to different input, and in order to explain the errors observed in our sample we must consider all the possible impacts which potentially affect learners (Krashen 1985). The literature has treated the role of input in foreign language learning (L2) differently: Ellis (1994) believed that all SLA theories attached different importance to the role of input in the language acquisition process, but basically acknowledged the need for language input. In many theories, SLA is considered an extremely important factor, while in other theories it is given a marginal role.

\begin{tabular}{|c|c|c|}
\hline input & intake & output (interlanguage) \\
\hline$\downarrow$ & $\downarrow$ & \\
\hline mother tongue & knowledge & language \\
- Lithuanian & of a second language & the learners speak \\
- Japanese & \\
- English & \\
- Bulgarian & \\
standard Serbian & \\
language dialect & \\
(urban variety of Niš) & \\
\hline
\end{tabular}

Fig. 1 Language material of students learning Serbian as L2 ${ }^{2}$

Figure 1 shows that possible influences in the creation of the interlanguage are of threefold nature, i.e. that students are influenced by the following: (a) the knowledge of their mother tongue - Lithuanian, Japanese, English or Bulgarian; (b) learning standard Serbian in an institutionalized settings - the classes they attended at the Centre for Serbian as a Foreign and Second Language; and (c) the Niš urban dialect spoken by young people in Niš, with whom the students spent hours and socialized in their free time. The middle

\footnotetext{
${ }^{2}$ The figure was created in accordance with the theoretical concepts of the input, intake and output described by Krashen (1985); such a methodology was also used in Sudimac (2019).
} 
column refers to the intake - it represents that part of the material which the learners successfully process and use to build their own internal understanding of a foreign language (VanPatten 1996). It may be the use of knowledge of another language which helps them or presents an obstacle in learning a foreign language (L2). The last column represents the final product of the combined action of the factors in the first and second column, which is the interlanguage (Ellis 1985) - the language spoken by the learners.

Since this paper deals with the analysis of errors at the phonetic-phonological and orthographic level of learning Serbian, all identified errors are classified as those resulting from (a) negative linguistic transfer and the impact of the mother tongue (L1) on learning a foreign language - Serbian (L2); (b) the complexity of the orthographic and phonological system of the Serbian language (so-called interlingual errors); (c) the uncertainty and insufficient mastery of the Serbian language; (d) the knowledge of some other language. Serbian consonants are represented by symbols of the International Phonetic Alphabet (IPA 1999).

\section{QUALITATIVE ERROR ANALYSIS}

\subsection{Affricates}

Given the structure of the phonological system of the Lithuanian language, the results are not surprising: the Lithuanian language, which has 11 vowels and 45 consonants (Mathiasen 1996, 21-31), includes all five affricates which also exist in standard Serbian, noting that the affricate $/ \mathrm{d} z /$ is a part of their standard language phonological system. The reflexes of each affricate unit in the domain of production are given below, showing that this learner has all five phonemes in her repertoire:

$/ \mathrm{d} z /=/ \mathrm{d} z /$ Džordžija, džezva, džak, džep, odžak, odžačar, adžija, pendžer, odžepariti, bedž, Tadž Mahal, Skrudž;

$/ \mathrm{t} f /=/ \mathrm{t} \mathrm{J} /$ čarape, čašica, čekati, čin, čanče, čekić, pčela, pečat, zvečka, ščepati, sačekati, kvidič, Beč, reč, meč, tač-daun, bič, grč, mač;

$\mid \mathrm{d} z /=/ \mathrm{d}$ l Đorđe, đumbir, đak, đavo, đuskati, grožđe, gospođa, rđav, vođa, gvožđe, ubeđivati, Buđanovci, buđenje, buđa, smuđa, čađa, riđa;

/t $6 /$ = /t $6 /$ ćilim, ćurka, ćošak, ćelav, ćup. mećava, šećer, kuća, pomoć, čekić, peć, noć, moć, Kać;

/ts/ = /ts/ cigla, cipele, crep, crevo, cverna, ocrniti, sncokret, potkovica, nec, mamac, vic, šlic, srce.

There were several misread examples where the learner pronounced the affricate /dz/ instead of the affricate /ts/: lanadz, otadz, shhlidz only in words in which it occupies the final position. This error occurred as a consequence of the influence of the mother tongue, in this case Lithuanian (negative linguistic interference), which recognizes the affricate /dz/, which is not part of the standard phonological system of the Serbian language.

Unlike the phonemic system of the Lithuanian language, which has more consonants, the Japanese language has five pure vowels and fifteen consonant units, four of which are affricates: $/ \widehat{\mathrm{ts}} /, / \overline{\mathrm{dz}} /, \widehat{/ \mathrm{t}} 6 /, / \widehat{\mathrm{d} z} /$ (Ohata 2004, 5-6). A greater number of errors was observed in the Japanese learner, and the production of each affricate had several different realizations:

$/ \mathrm{d} z / \approx / \mathrm{d} 3 /$ Džordžija, adžija, pendžar, Skrudž;

$/ \mathrm{d} z / \approx / \mathrm{d} z /$ đezva, đak, đep, ođepariti, beđ, Tađi Mahal;

$/ \mathrm{d} z /=/ \mathrm{d} /+/ \mathrm{d} z /$ oddžak, oddžačar. 
These examples show that the level of acquisition of the affricate /dz/ is the lowest since this learner read it in three different ways: (a) similar to the affricate $/ \mathrm{d}_{3} /$ from standard Serbian; (b) similar to the affricate /dz/ or the soft $/ \mathrm{dz}^{\prime} /$ which is the consequence of not being able to distinguish between two affricate pairs; or (c) as a combination of two separate units: the one being the plosive /d/ and the other being the affricate $/ \mathrm{d} z /$. On the phonological level, the learner should acquire the phoneme /dz/ which she does not have in her mother tongue. The examples in the first line show that it exists, but there are often cases in which the learner pronounces it as a softened $/ \mathrm{d}^{\prime} /$, that is $/ \mathrm{d} z /$.

$/ \mathrm{t} \mathrm{J} / \approx / \mathrm{t} /$ čarape, čašica, čekati, čanče, čekić, pčela, svečka, sčepati, sačekati, kvidič, tač-daun, bič, grč, mač;

$/ \mathrm{t} \mathrm{g} / \approx / \mathrm{t} 6 /$ ćin, ćekić, reć, meć, pećat.

The affricate $/ \mathrm{t} f /$ is pronounced as (a) $/ \mathrm{t} f /$ and (b) $/ \mathrm{t} c /$. In this case, too, the learner has the task to acquire the phoneme $/ \mathrm{t} /$ which does not exist in te Japanese and distinguish between $/ \mathrm{t} / /$ and $/ \mathrm{t} 6 /$, which are two different phonemes in the Serbian language.

$|\mathrm{d} z|=/ \mathrm{d}$ ol Đorđe, đumbir, đak, đavo, đuskati, grožđe, gospođa, rđav, vođa, gvožđe, ubeđivati, Buđanovci, buđenje, buđ, smuđ, čađ, riđ.

/tø/ = /tø/ ćilim, ćurka, ćošak, ćelav, ćup, mećava, šećer, kuća, pomoć, čekić, peć, noć, $m o \dot{c}, K a c^{\prime}$

/ts/ = /ts/ cigla, cipele, crevo, crvena, ocrniti, sncokret, potkovica, nec, lanac, mamac, vic, šlic, otac.

These examples show that the learner managed to acquire the affricates $/ \mathrm{d} z /, / \mathrm{t} 6 /$ and /ts/ and that she did not make any errors in this domain.

Bearing in mind the presented structure of the phonological system of the Japanese language, we see that the errors in the production of the affricates $/ \mathrm{d} z /$ and $/ \mathrm{t} / \mathrm{w}$ were due to their non-existence in the Japanese language, and the learner was trying to find a number of differential substituents for their realization; the satisfactory acquisition of affricates $/ \mathrm{d} z /, / \mathrm{t} 6 /$ and $/ \mathrm{ts} /$ is a consequence of their existence in the Japanese language.

The last example $/ \mathrm{ts} /=/ \mathrm{k} /$ krep illustrates the use of mechanism and rules for reading from a language which the learner knows, in this case English, where the sequence $c r$ at the beginning of a word should be read as $k r$.

The English language has 24 consonant units which differ from each other based on the place and manner of articulation. Of the total number of consonant units, two are phonemes which are classified as affricates - the voiced $/ \mathrm{d}_{3} /$ and voiceless $/ \mathrm{t} / \mathrm{l}$. In the English language, these phonemes have palato-alveolar (postalveolar) articulation. On the other hand, the Serbian language has five phonemic units - affricates, and the articulation is dental /ts/, that is, alveolar /ťs, dž/ and post-dental /tj, dj/, indicating a somewhat more complex picture in relation to the English language (Petrović, Gudurić 2010, 260-276). The analysis of the examples in our paper indicates that there are two problems on two levels regarding the learner whose mother tongue is English: (a) on the phonological level, where there is one phoneme $/ \mathrm{d}_{3} /$ in the mother tongue, and in the foreign language there are two $/ \mathrm{d} 3, \mathrm{~d} z /$, that is, $/ \mathrm{t} f /$, and in Serbian $/ \mathrm{t} f$, $\mathrm{t} 6 /$, so the learner must decompose one phoneme into two and acquire them as separate phonemic units; and (b) the influence of the mother tongue is also reflected at the phonetic level because the interference is reflected in the transfer of the place of articulation from the English language. All of the examples listed below confirm that the influence of the mother tongue is also reflected on the phonological level where the learner retained the phoneme from English, but it is also reflected on the phonetic level - in cases where she produced a phoneme similar to Serbian, she did so with a place of articulation peculiar to her mother tongue. 
$/ \mathrm{d} 3 / \approx / \mathrm{d} 3 /$ Džordžija, bedž, Tadž Mahal, Skrudž;

$/ \mathrm{d} 3 / \approx / \mathrm{d}^{\prime} /$ đevđa, đak, đep, ođak, ođaćar, ađija, ođepariti, penđer;

$/ \mathrm{t} \mathrm{f} / \approx / \mathrm{t} 6 /$ ćarape, ćašica, ćekati, ćanće, ćekić, pćela, pećat, svećka, sćepati, saćekati, kvidić, reć, meć, tać-daun, bić, grć, mać.

A particularly interesting situation was noted during the production of the affricate /ts/. In some examples it was successfully produced (ocrniti, potkovica, nec, lanac, mamac, vic, šlic, otac); whereas in other cases, instead of /ts/ the plosive / $\mathrm{k} /$ was pronounced, in the position in front of the sonant $/ \mathrm{r} /$. This error was made under the influence of the mother tongue because in it the sequence cr should be read / $/ \mathrm{kr} /$ : krep, krevo, sunkokret; the third recorded situation is due to the effect of the generalization of the rule according to which the consonant /c/ in front of the vowel /e/ should be read as /s/: thus, the learner read the word centar as sentar and applied the same rule in the following examples: sigla, sipele, srvena, osrniti, srn, srven, srsi.

Finally, the results are given for the female learner whose mother tongue is Bulgarian, which belongs to the Slavic language group, so we expected the number of errors to be smaller. The results of the production of affricates are presented in the following paragraphs:

$/ \mathrm{d} 3 /=/ \mathrm{d} 3 /$ odžak, odžačar, adžija, pendžer, Skrudž;

$/ \mathrm{d} 3 /=/ \mathrm{d} z /$ Đorđija, đak, đezva, đep.

The first examples illustrate the existence of errors as a result of insufficient knowledge of the Serbian language: the example Dordija could have also originated through analogy with the name Đorđe.

$\mid \mathrm{t} / /=/ \mathrm{t} J /$ čarape, čašica, čekati, čin, čanče, čekić, pčela, pečat, zvečka, ščepati, sačekati, kvidič, Beč, reč, meč, tač-daun, bič, grč, mač;

$/ \mathrm{d} z /=/ \mathrm{d} z /$ Đorđe, đak, đavo, đuškati, grožđe, gospođa, ubeđivati, Buđanovci, buđenje.

The example $/ \mathrm{d} \mathrm{z} /=/ \mathrm{t} 6 /$ smuć indicates the devoicing of the final voiced consonant $/ \mathrm{d} z /$, which represents a common occurrence which applies to most speeches.

On the other hand, no errors were observed in the production of the affricates $/ \mathrm{t} \mathrm{c} / \mathrm{and} / \mathrm{ts} /$ : Kać;

/t6/ = /t $6 /$ ćilim, ćurka, ćošak, ćelav, ćup, mećava, šećer, pomoć, čekić, peć, noć, moć,

/ts/ = /ts/ cigla, cipele, crep, crevo, crvena, ocrniti, sncokret, potkovica, nec, lanac, mamac, vic, šlic, srce, otac.

Based on the analyzed errors, we can conclude that the majority of errors in the production of affricates were due to the influence of the mother tongue on Serbian or the lack of acquisition of standard Serbian at the time when the research was conducted. The smallest number of errors were of the interlingual type where the analogy mechanism was used.

\subsection{Other errors occurring under the influence of the mother tongue}

It is noticeable that the learner whose mother tongue is Lithuanian was unable to produce a word which contains a four-member consonant group: she read ostro (VCCCV) instead of ostrvo (VCCCCV). So, we noted the mechanism of losing the sonant $/ \mathrm{v} /$ : the learner creates a three-member consonant group which she is able to pronounce, and the reason is that in Lithuanian the largest number of consonants within one syllable is three (CCC). At the orthographic level, the Lithuanian learner made two errors which occurred as a result of negative language interference and the influence of her mother tongue on the acquisition of a foreign language: (a) instead of $\langle u\rangle$ the learner used the grapheme $\langle y\rangle$ in 
examples where the vowel had a long accent: Syma, zyd, Šyd. In the Lithuanian language at the orthographic level there are special graphemes for the short and long $\langle\mathrm{u}\rangle$, and precisely the grapheme $\langle y\rangle$ is used to denote long accent quantity; (b) the second error involved writing the consonant $\langle\mathrm{h}\rangle$ where the digraph $\langle\mathrm{ch}\rangle$ was used: chol, chrana, chleb.

Having in mind the open syllable rule in Japanese ${ }^{3}$, it was observed that the learner from Japan tried to obey the rule in her native language when speaking, breaking up two or three members of the Serbian consonant group by using a semivowel: $p-\partial-\check{c}$ ela; $g$ - $ə$ - vož - a - đe; s - a - muđ - a; Bu - đa-nov - a - ci; $\check{s}-$ - - lic - ə; ćur - a - ka. She also applied this rule at the orthographic level by adding an additional element to one-syllable words ending in a consonant, thus creating an open syllable: nožu, pužu, mužu, dužu.

Another error which occurred as a result of the negative language interference was the inability to differentiate between the sonorants $/ \mathrm{r} /$ and $/ \mathrm{l} /$, which was manifested on the orthographic level: in every case in which a word with the grapheme $<1>$ should have been written, the learner wrote $\langle\mathrm{r}\rangle$ : prinu (plin), nariti (naliti), orovka (olovka). This happened because there are two separate phonemes in the Serbian language $/ \mathrm{r} /$ and $/ \mathrm{l} /$, which is not the case in Japanese: there is only the phoneme /r/, whereas /l/ is one of the allophone realizations of this phoneme. The influence of the Japanese language in this respect was also manifested in the production of the phoneme $/ \mathrm{r} /$. At the orthographic level, instead of the consonant $\langle\mathrm{f}\rangle$, the learner wrote the consonant $\langle\mathrm{h}\rangle$ : breh (blef), tleh (tref). The occurrence of this error was caused by the absence of the grapheme $\langle\mathrm{f}\rangle$ in Japanese.

Finally, a phenomenon related to the quality of the closed (low) vowel /u/ was also observed. In Serbian, the primary point of articulation of this sound is the posterior palate, and the secondary are the lips, meaning that $/ \mathrm{u} /$ in Serbian is rounded, while in Japanese there is an unrounded vowel [u]. That is why the learner read all the examples with this vocal closed, without using her lips as an auxiliary place of articulation: ćup, ćurka, kuća, suncokret. Therefore, the analyzed examples indicate the interference of the mother tongue at the phonetic level: the learner has the phoneme /u/, but its phonetic realization is the same as in the mother tongue - this, however, needs to be confirmed experimentally. Another example has to do with the phonotactic constraints which are transmitted from the Japanese language to the foreign language: the group /st/ is not allowed in Japanese, so the learner read the examples stajati and rastajati as spajati and raspajati. When pronouncing the constituent euro in the name of the bank Eurobanka, in the spirit of her mother tongue, the student produced: Jurobanka.

The analysis of the examples shows that during the production of the sonant $/ \mathrm{r} /$ there is an interference on the phonetic level: in Serbian it is an alveolar vibrant (Petrović, Gudurić 2010), and in English ${ }^{4}$ a retroflex postalveolar approximant from her mother tongue. The learner transferred both the place and the manner of articulation, which was manifested in the pronunciation of the following examples: /prst/, /dobro/, /strah/, /srce/.

The data analysis we used to check the acquisition of the sonant $r$ (vocalic $r$ ) indicated that the learner pronounced a number of examples with a semivowel: the influence of the mother tongue was reflected in the examples read with the vowel schwa which exists in Bulgarian as a phoneme (at the orthographic level $\langle\mathrm{b}\rangle$ ) in the following examples: Sarbija, Sarbin, parst, karst, garčki, smart, tarn, darvo, parvi, sarce. In the examples trg,

\footnotetext{
${ }^{3}$ A syllable must end in a vowel or nasalized sound $/ \mathrm{m} /, / \mathrm{n} /$ or $/ \mathrm{ng} /$ (Ohata 2004)

${ }^{4}$ Ladefoged 2006, 15 describes the sound /r/ as an alveolar approximant. It is also characterized by secondary articulation - labialization and velarization (Odgen 2009, 91).
} 
rđav, trgnuti se, crn, crven, crv, žanr, grb, which are different in her mother tongue, the vowel schwa was not pronounced. The learner from Lithuania read all analyzed examples in which the production of vocalic $r$ was checked without making an error: Srbija, Srbin, trg, prst, krst, rđav, rt, smrt, trgnuti se, crn, trn, crven, crv, žanr, grb, grćki, prvi, srce

The learner from Bulgaria read the example pomoć as pomoš: the example also points out the impact of the mother tongue because the lexeme pomoc has the same form in Bulgarian: nомощ /pomošt/. In some examples, there is a devoicing of final voiced consonants: smuć, blev, trev, grp. This a general phenomenon which is characteristic of many languages. On the orthographic level, the influence of Bulgarian was reflected in the use of the grapheme $<\breve{\mathrm{n}}>$ instead of the grapheme $<\mathrm{j}>$, in the examples in which this grapheme occupied the medial or final position: брой, твой, бойица, војйник, Бойник.

\subsection{Interlingual errors}

At the orthographic level, the learner whose native language is English made the most errors by mixing graphemes from two different scripts, where the learner knows two systems exist, but errors occur due to insufficient acquisition and the mixing of sounds which have different orthographic values ${ }^{5}$ : instead of selo the learner writes celo, and instead of Sima the learner writes Cima. This means that the graphemes $\langle\mathrm{s}\rangle$ and $<\mathrm{c}>$ were mixed.

In all learners we noted the mixing of affricates $<\amalg, ~ ч, ~ \hbar, ~ \hbar, ~ ц>$ when transcribing the text from Cyrillic to Latin script: ćistih, osuđeno, ćudo, ćuđenje. In the learner whose mother tongue is English, at the orthographic level, we noticed the mixing of the fricatives $\langle\check{z}\rangle$ and $\langle\mathrm{z}\rangle$, so we have the following examples: žid, pažiti, paznja, vož. In the learner whose mother tongue is Japanese, at the orthographic level, we noted the mixing of the palatal consonants $\langle\mathrm{lj}\rangle$ and $\langle\mathrm{nj}\rangle$ : divnjenje, ljuška, nevidnjivo.

Most errors of the interlingual type were observed in the third exercise which tested the knowledge of semantics of given lexemes in which a consonant or a vowel phoneme bears a distinction in semantic terms. All of the learners made mistakes, mostly in the pairs BečBedž, trag - vrag and naš - vaš. When testing the content of the given lexemes in isolatation, the learners did not make mistakes - because these were lexemes which had been analyzed in class previously and could be found in the Dictionary at the end of the textbook they used. When the same lexemes were in different conditions, mistakes were made, which means that the abovementioned context made the task more difficult.

\section{CONCLUSION}

Knowing that one of the goals of foreign language teaching is its successful use in everyday communication, it is expected that students will master the content from all language levels of the target language (L2). Therefore, one of the main tasks is to master the phonological system and the orthography of standard Serbian. Practice shows that due to the complexity of these systems, learners make errors when pronouncing basic phonemes as well as writing them.

Based on the analysis of the sample, we can draw several concluding observations and remarks. First, although the rules for the orthographic level are simpler in Serbian (L2) than the rules in the native languages of the learners (L1), errors were due to the existence of two

\footnotetext{
${ }^{5}$ In Serbian, the phoneme $/ s /$ is written in grapheme $\langle c\rangle$ in Cyrillic and in grapheme $\langle s\rangle$ in Latin script.
} 
scripts, indicating the fact that such errors occur as a consequence of the complexity of the system within a language. Second, errors at the orthographic level were also influenced by superdifferentiation, that is, by the influence of the mother tongue, indicated in replacing the grapheme values of one unit with values from the mother tongue (for example, $<_{\mathrm{h}}>=$ $\langle\mathrm{y}\rangle,\langle\mathrm{h}\rangle=\langle\mathrm{ch}\rangle$ ). On the phonetic-phonological level, most errors were due to the influence of the mother tongue on the $\mathrm{L} 2$, which is expected given that most elements from the mother tongue are transferred to the phonological system of the foreign language, while at the higher language levels (morphological, syntactic) errors of another type were recorded (see Sudimac 2019, 451).

Acknowledgement: The paper was written as a part of a project of the Faculty of Philosophy, University of Niš, Srpski jezik nekad i sad: lingvistička istraživanja (project number 360/1-16-1001), as well as a part of a project realized within the SASA Niš branch Govorni i standardni jezik u javnoj komunikaciji u Nišu (O-25-20).

\section{REFERENCES}

Arsić Perišić, O. 2016. “Analiza grešaka u srpskom jeziku kao stranom na primeru italofona”. Srpski jezik kao strani u teoriji i praksi III (2016): 155-168.

Babić, B. (2016). Unutarjezičke greške na početnim nivoima učenja srpskog jezika kao stranog. In Serbian. Unpublished doctoral dissertation. University of Novi Sad, Faculty of Philosophy.

Best, C. 1995. "A direct realist view of cross-language speech". In W. Strange (ed.), Speech perception and linguistic experience. Baltimore: Yourk press: 171-204.

Đorđević, K. 2017. “Analiza grešaka slovačkih maternjih govornika na početnom nivou učenja srpskog jezika kao stranog”. Studia Balkanica Bohemo-Slovaca VII, Brno: Moravské zemské muzeum Ústav slavistiky Filozofické fakulty Masarykovy university: 691-697.

Ellis, R. 1985. Sources of variability in interlanguage. Applied Linguistics, 6, 2: 118-131.

Ellis, R. 1994. The Study of Second Language Acquisition. Oxford: Oxford University Press.

Flege, J. E. 1993. "Production and perception of a novel, second language phonetic contrast". Journal of the Acoustical Society of America 93 (3): 1589-1608.

Flege, J. E. 1995. "Second language speech learning: Theory, findings and problems". In W. Strange (ed.), Speech perception and linguistic experience: Issues in cross-language speech research. Timonium MD: York Press: 233-277.

IPA. 1999. Handbook of the International Phonetic Association: A Guide to the Use of the International Phonetic Alphabet. Cambridge: Cambridge University Press.

Krashen, S. 1985. Second Language Acquisition and Second Language Learning. New York and Oxford: Pergamon Press Ltd.

Ladefoged, P. A course in phonetics (5th ed.). Belmont, CA: Thompsom Wadsworth.

Mathiassen, T. 1996. A short grammar of Lithuaninan. Ohio (USA): Slavica Publishers.

Milošević, S. 2016. “Tipologija gramatičkih grešaka ruskih govornika pri usvajanju srpskog jezika”. Srpski kao strani jezik u teoriji i praksi III: 169-180.

Novaković, A. 2018. "Didaktičko-metodička oblikovanost radne sveske za učenje srpskog i engleskog jezika kao stranog - kontrastivni pristup". Godišnjak za srpski jezik, br. 16, XXIX: 75-94.

Novaković, A. 2019. "Kontrastivna analiza sadržaja i didaktičke oblikovanosti udžbenika za učenje srpskog i engleskog jezika kao stranog”. Godišnjak za srpski jezik, br. 17, god. XXX: 65-87.

Ohata, K. 2004. "Phonological differences between Japanese and English: Several potentially problematic areas of pronunciation for Japanese ESL/EFL learners". Asian EFL Journal, 6(4).

Petrović, D., Gudurić, S. 2010. Fonologija srpskoga jezika. Beograd: Institut za srpski jezik SANU - Novi Sad: Matica srpska - Beograd: Beogradska knjiga.

Sudimac, N. 2019. "Najčešće greške prilikom usvajanja srpskog jezika kao stranog kod studenata rumunske nacionalnosti”. Ishodišta 5, Temišvar: Savez Srba u Rumuniji - Centar za naučna istraživanja i kulturu u Rumuniji - Filozofski fakultet Univerziteta u Nišu, godina 5, broj 5: 441-455. 


\section{ANALIZA GREŠAKA NA FONETSKO-FONOLOŠKOM I ORTOGRAFSKOM PLANU KOD UČENJA SRPSKOG JEZIKA KAO STRANOG}

U radu se iz ugla primenjene lingvistike govori o usvajanju srpskog jezika kao stranog kod studenata kojima su maternji jezici litvanski, japanski, engleski i bugarski, a koji su jedan semestar proveli u Centru za srpski jezik kao strani i nematernji na Filozofskom fakultetu u Nišu. Cilj rada je da se na konkretnom korpusu, pomoću analitičke i metode analize grešaka, identifikuju najčešće greške na fonetsko-fonološkom i ortografskom planu, zatim da se izvrši njihova deskripcija i eksplanacija. Takođe, identifikovane jezičke greške razvrstane su prema tipu na one: (a) koje su nastale pod uticajem maternjeg jezika; (b) koje su posledica težine samog sistema srpskog jezika - unutarjezičke greške; (c) koje proističu zbog poznavanja drugog jezika i (d) i na kraju, na one koje su posledica nesigurnosti $i$ nedovoljne usvojenosti srpskog jezika. Analizom korpusa zaključujemo da je najveći broj grešaka na fonetsko-fonološkom i ortografskom planu nastao zbog uticaja maternjeg jezika (L1) na srpski (L2).

Ključne reči: analiza grešaka, fonetsko-fonološki nivo, ortografski nivo, srpski kao strani (L2) 